\title{
THE IMPACT OF MICROCLIMATE PARAMETERS ON ODOUR EMISSIONS FROM PIG PRODUCTION IN SPRING
}

\author{
WPLYW PARAMETRÓW MIKROKLIMATU NA EMISJE ODORÓW \\ Z TUCZARNI W OKRESIE WIOSENNYM
}

\begin{abstract}
The aim of this study was to examine the impact of inside temperature and relative humidity, ventilation rate and gas concentrations $\left(\mathrm{NH}_{3}, \mathrm{~N}_{2} \mathrm{O}, \mathrm{CO}_{2}\right)$ on odour emissions from deep-litter piggery. The studied facility had temperature-controlled mechanical ventilation. The measurements were conducted from March to June 2014. During the research, selected microclimate parameters, as well as number and mass of animals were monitored and air samples were collected (two samples of air in each series of measurements). Temperature and relative humidity were measured using Testo 435-4 multifunctional measuring instrument. To measurements of gas concentrations was used the photo-acoustic spectrometer Multi Gas Monitor Model 1312. The concentration of odours in the air samples was determined by dynamic olfactometry with the TO 8 olfactometer, according to PN-EN 13725:2007. The odour concentration ranged from 450 to $2004 \mathrm{ou}_{\mathrm{E}} \cdot \mathrm{m}^{-3}$ (mean $1048 \mathrm{ou}_{\mathrm{E}} \cdot \mathrm{m}^{-3}$ ) and the mean odour emission factor was from 5.76 to $46.79 \mathrm{ou}_{\mathrm{E}} \cdot(\mathrm{s} \cdot \mathrm{pig})^{-1}$ (mean $20.93 \mathrm{ou}_{\mathrm{E}} \cdot(\mathrm{s} \cdot \mathrm{pig})^{-1}$. The statistical analysis showed that the inside temperature explained most of the variability of the odour concentration and the relationship was described by equation: $c_{o d}=5634-197 T_{\text {inside }}\left(R^{2}=0.82, p \leq 0.05\right)$. For odour emission factor, two parameters: the inside temperature and ventilation rate, explained most of the variability, according to the equation: $E F_{o d}=108+1939 V R-5.5 T_{\text {inside }}\left(R^{2}=0.81, p \leq 0.05\right)$.
\end{abstract}

Keywords: odour concentration, odour emission factor, deep-litter piggery, microclimate

\section{Introduction}

Agriculture is one of the economy sectors, whose main role is to provide plant and animal products. Activity in this sector is associated with a negative impact on the environment. Intensive livestock farming causes many serious threats, which are not limited only to the farming area [1,2]. One of them is the odour emission. Unpleasant and onerous odours, arising from the livestock production, are the main reason of discomfort for people living close to pigs, cattle or poultry farms [3,4]. Besides causing the discomfort of people, odours may affect their mood and behaviour [5]. Human reaction to the odours depends on:

\footnotetext{
${ }^{1}$ Department of Environmental Management in Livestock Buildings and Air Protection, Institute of Technology and Life Sciences, ul. Biskupińska 67, 60-463 Poznań, Poland, phone +48 2262837631

${ }^{2}$ Institute of Environmental Engineering, Poznan University of Technology, Berdychowo 4, 60-965 Poznań, Poland, phone +48 6166524 38, fax +48 6166524 39, email: wojciech.rzeznik@put.poznan.pl

*Corresponding author: p.mielcarek@itp.edu.pl
} 
the amount and character of odours, the distance between inhabited area and the source of emissions, weather conditions, topography and individual sensitivity and tolerance [6].

Hardwick [7] showed that approximately $50 \%$ of all the odour complaints associated with agriculture were a result of the land application of manure, with the remaining complaints split $20 \%$ to manure storage and $30 \%$ to the production buildings. The formation of odorants is due to microbial activity, especially the incomplete anaerobic decomposition of organic matter, particularly proteins and carbohydrates, in the animal faeces $[8,9]$. Many factors may affect the odour emissions from livestock buildings: animal species and their age, activity of the animals, housing system, type of feed and microclimatic conditions in livestock buildings [10-12]. One of the factors which can be controlled is microclimate, so microclimate control may be a way to reduce odour emissions. This requires determining which of the microclimate parameters and how strongly affect the odour quality of air in the livestock buildings. Due to a lot of factors affecting the microclimate parameters, the identification is difficult. Thereby controlling of microclimate parameters and observation of their effect on the concentration of odours still require further studies.

The aim of this study was to examine the impact of inside air temperature, relative air humidity, ventilation rate and gas concentrations $\left(\mathrm{NH}_{3}, \mathrm{~N}_{2} \mathrm{O}, \mathrm{CO}_{2}\right)$ on odour emissions from pig facility in spring.

\section{Material and methods}

\section{Research object}

The study about the impact of selected microclimate parameters on odour emissions from piggery was carried out from March to June 2014. The measurements were made in the 10-rooms deep-litter piggery (Fig. 1), where pigs were fattened in 3.5-month open cycle $(25-110 \mathrm{~kg})$. Measurements were carried out in one of the rooms, which had two pens, each for 50 pigs. The area per pig was equal to $0.77 \mathrm{~m}^{2} \cdot \mathrm{pig}^{-1}$. The piggery was equipped with a mechanical negative pressure ventilation system, which was controlled by temperature. The studied room was ventilated by two fans with a maximum efficiency of $6250 \mathrm{~m}^{3} \cdot \mathrm{h}^{-1}$ each (maximum ventilation rate per pig $125 \mathrm{~m}^{3} \cdot(\mathrm{h} \cdot \mathrm{pig})^{-1}$.

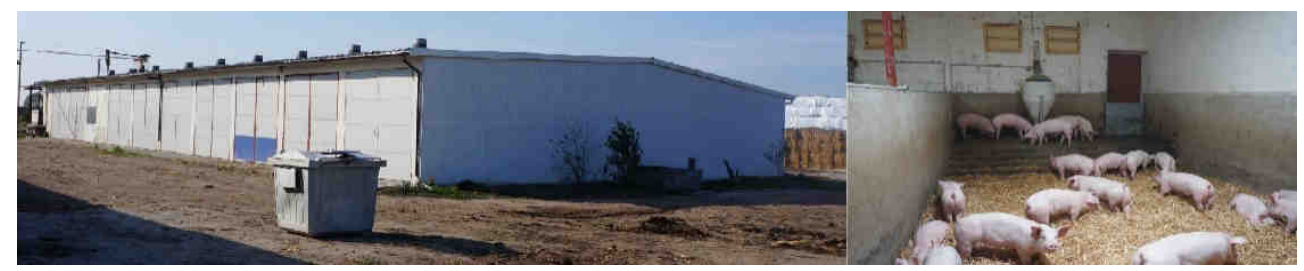

Fig. 1. The studied piggery

\section{Air sampling}

During the study, 14 series of measurements were made and 28 air samples were collected in piggery. The sampling point was located close to the ventilation duct removing air from the building (Fig. 2). In the morning between 9:00 and 11:00, two air samples were collected in piggery, for each series of measurements. The sampling time was 5 minutes. 
The air was collected to disposable $8 \mathrm{dm}^{3}$ bags made of Nalophan (PET) using the ECOMA CSD30 sampler.
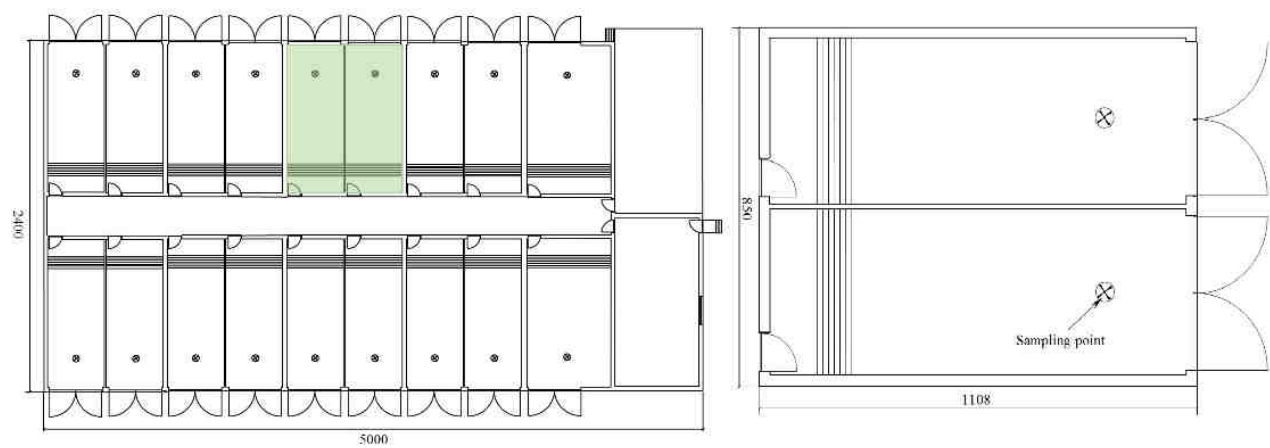

Fig. 2. The layout of the studied piggery and room

\section{Microclimate parameters}

To determine the effect of microclimatic conditions inside the piggery on the concentration and emission of odours, the air temperature and relative humidity, ventilation rate and concentration of selected gases $\left(\mathrm{NH}_{3}, \mathrm{~N}_{2} \mathrm{O}\right.$ and $\left.\mathrm{CO}_{2}\right)$ were monitored inside the building. The ammonia is one of the strongest odorants in piggeries, and the nitrous oxide even in low concentration disrupts the human nervous system and can affect the human sense of smell $[13,14]$. The carbon dioxide concentration is the indicator of ventilation efficiency [15]. The Testo 435-4 multifunctional measuring instrument was used to measure temperature and relative humidity (accuracy $0.2{ }^{\circ} \mathrm{C}$ and $2 \%$, respectively). The ventilation rate was determined on the basis of the momentary percentage fans efficiency provided by the SK-1D2M climate controller (Wesstron, Poland) and the characteristics of fans. Gas concentrations were measured every minute during the air samples collection and at the same point, where air samples were collected. The photo-acoustic spectrometer Multi Gas Monitor Model 1312 was used to measure the concentration of studied gases (Fig. 3). It was equipped with the filters: type UA 0976 for $\mathrm{NH}_{3}$ (detection limit - $0.15 \mathrm{mg} \cdot \mathrm{m}^{-3}$ ), type UA 0985 for $\mathrm{N}_{2} \mathrm{O}$ (detection limit $0.06 \mathrm{mg} \cdot \mathrm{m}^{-3}$ ) and type UA 0983 for $\mathrm{CO}_{2}$ (detection limit $-9.89 \mathrm{mg} \cdot \mathrm{m}^{-3}$ ).

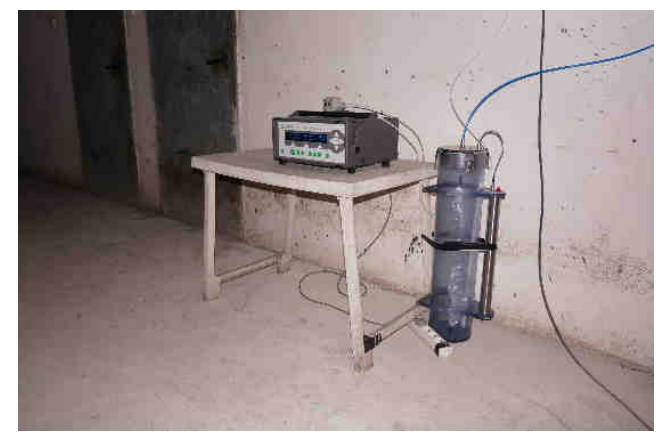

Fig. 3. The photo-acoustic spectrometer Multi Gas Monitor Model 1312 and sampler 


\section{Odour concentration}

The air samples were analysed within 24 hours from the collection in accredited olfactometric laboratory of the Institute of Technology and Life Sciences in Poznan. The concentration of odours was determined using dynamic olfactometry and TO 8 olfactometer, according to PN-EN 13725:2007 [16]. Each time, the assessment of odour concentration was carried out by the same team of four experts. This team has been selected basing on the result of marking individual odour threshold using n-butanol as a gas indicator. The method yes/no was used for the assessment of the odour concentration.

\section{Odour emission}

Momentary odour emission rate $E_{o d}\left[\mathrm{ou}_{\mathrm{E}} \cdot \mathrm{s}^{-1}\right]$ from studied piggery was calculated as the product of the odour concentration $c_{o d}\left[\mathrm{ou}_{\mathrm{E}} \cdot \mathrm{m}^{-3}\right]$ and the ventilation rate $V R\left[\mathrm{~m}^{3} \cdot \mathrm{s}^{-1}\right]$, according to the following equation:

$$
E_{o d}=c_{o d} \cdot V R
$$

The value $c_{o d}$ used for analysis was the geometric mean of odour concentration in two samples. The calculated momentary odour emission was gross value (concentration of odours in inlet air was negligibly low). In order to examine the effect of microclimate parameters on odour emission, the odour emission factor $E F_{\text {od }}\left[\mathrm{ou}_{\mathrm{E}} \cdot(\mathrm{s} \cdot \mathrm{pig})^{-1}\right]$ was used the odour emission expressed per pig. The mean body mass of the pig, in each measurement day, was the arithmetic mean of mass of 10 randomly selected pigs.

\section{Statistical analysis}

The statistical analysis was made using the Statistica 12 software. The analysis of measured data was carried out by means of multiple regressions. The dependent variables were odour concentration and odour emission factor. The total number of independent variables considered in the regression analysis was six: inside air temperature, inside relative air humidity, ventilation rate and concentrations of $\mathrm{NH}_{3}, \mathrm{~N}_{2} \mathrm{O}$ and $\mathrm{CO}_{2}$. However, the effects of all parameters were not necessarily significant. A stepwise procedure (backward elimination) was used on all possible subset regressions. The regression models were then arranged in a decreasing order of adjusted determination coefficient, $R^{2}$.

\section{Results and discussion}

\section{Microclimate parameters}

During the research the number of pigs in studied room was close to nominal livestock density and ranged from 99 to 101 pigs. The mean body mass of one pig was equal to $63.6 \mathrm{~kg}(41.3-85.2 \mathrm{~kg})$. The mean values of selected microclimate parameters, measured at 14 measurement series, are presented in Table 1.

Thermal conditions in fattening house depended on the outside temperature. The inside temperature was higher than the theoretical optimum temperature $\left(12-18{ }^{\circ} \mathrm{C}\right)$. Relative humidity was also higher than the optimal value (60-70\%) [17]. It results from the specific conditions in deep-litter piggeries. The exothermic processes occurring in the fermenting litter raised its temperature, causing the increased release of water vapour. The air cooling systems usually are not used in commercial pig houses, in temperate climate. Generally, the value of $\mathrm{CO}_{2}$ concentration was lower than the limit value $-5280 \mathrm{mg} \cdot \mathrm{m}^{-3}$, which indicates proper operation of the ventilation system [17]. 
The mean values of selected microclimate parameters

\begin{tabular}{|c|c|c|c|c|c|c|}
\hline \multirow[t]{2}{*}{ Date } & \multirow{2}{*}{$\begin{array}{c}\text { Temperature } \\
{\left[{ }^{\circ} \mathbf{C}\right]}\end{array}$} & \multirow{2}{*}{$\begin{array}{c}\text { Relative } \\
\text { humidity } \\
{[\%]}\end{array}$} & \multirow{2}{*}{$\begin{array}{l}\text { Ventilation rate } \\
{\left[\mathrm{m}^{3} \cdot(\mathrm{s} \cdot \mathrm{pig})^{-1}\right]}\end{array}$} & \multicolumn{3}{|c|}{$\begin{array}{c}\text { Concentration } \\
{\left[\mathbf{m g} \cdot \mathbf{m}^{-3}\right]}\end{array}$} \\
\hline & & & & $\mathrm{NH}_{3}$ & $\mathrm{~N}_{2} \mathrm{O}$ & $\mathrm{CO}_{2}$ \\
\hline 25.03 .2014 & 19.0 & 91.2 & 0.003 & 37.16 & 1.88 & 6647 \\
\hline 26.03 .2014 & 20.6 & 88.6 & 0.012 & 23.94 & 1.79 & 5024 \\
\hline 27.03 .2014 & 20.9 & 95.2 & 0.013 & 22.92 & 0.96 & 4725 \\
\hline 15.04 .2014 & 19.6 & 89.8 & 0.014 & 12.27 & 1.09 & 4307 \\
\hline 16.04 .2014 & 19.2 & 75.0 & 0.012 & 23.62 & 1.36 & 4243 \\
\hline 17.04 .2014 & 20.2 & 72.4 & 0.018 & 19.94 & 1.20 & 3877 \\
\hline 24.04 .2014 & 23.2 & 87.4 & 0.031 & 14.68 & 1.06 & 3563 \\
\hline 25.04 .2014 & 22.8 & 81.9 & 0.030 & 16.64 & 1.18 & 3315 \\
\hline 20.05 .2014 & 23.7 & 64.4 & 0.018 & 10.21 & 0.90 & 2195 \\
\hline 21.05 .2014 & 25.3 & 67.6 & 0.027 & 4.02 & 0.80 & 1909 \\
\hline 22.05 .2014 & 25.4 & 63.5 & 0.028 & 5.96 & 0.71 & 2202 \\
\hline 10.06 .2014 & 24.9 & 82.0 & 0.022 & 5.16 & 0.86 & 2515 \\
\hline 11.06 .2014 & 25.5 & 71.5 & 0.025 & 8.74 & 0.83 & 2501 \\
\hline 12.06 .2014 & 25.3 & 74.0 & 0.024 & 10.74 & 0.84 & 2598 \\
\hline
\end{tabular}

\section{Odour concentration}

In the studied period the values of odour concentration varied from $450 \mathrm{ou}_{\mathrm{E}} \cdot \mathrm{m}^{-3}$ to $2004 \mathrm{ou}_{\mathrm{E}} \cdot \mathrm{m}^{-3}$ and the mean was $1048 \mathrm{ou}_{\mathrm{E}} \cdot \mathrm{m}^{-3}$ (Table 2). The changes of odour concentration were opposite to temperature changes in studied piggery. High odour concentrations were noted when the inside temperature was low, and during warm days the odour concentration was quite low.

Table 2

Determined mean values of odour concentration for each day of measurement

\begin{tabular}{|c|c|}
\hline Date & $\begin{array}{c}\text { Odour concentration } \\
{\left[\mathbf{o u}_{\mathbf{E}} \cdot \mathbf{~ m}^{-\mathbf{3}} \mathbf{]}\right.}\end{array}$ \\
\hline 25.03 .2014 & 1649 \\
\hline 26.03 .2014 & 1649 \\
\hline 27.03 .2014 & 2004 \\
\hline 15.04 .2014 & 1685 \\
\hline 16.04 .2014 & 1798 \\
\hline 17.04 .2014 & 1387 \\
\hline 24.04 .2014 & 1512 \\
\hline 25.04 .2014 & 1245 \\
\hline 20.05 .2014 & 899 \\
\hline 21.05 .2014 & 501 \\
\hline 22.05 .2014 & 650 \\
\hline 10.06 .2014 & 450 \\
\hline 11.06 .2014 & 636 \\
\hline 12.06 .2014 & 535 \\
\hline
\end{tabular}

There are only few papers about odour concentration in deep-litter systems for pigs. Wang et al. [18] conducted study in experimental room and noted mean odour concentration - $67.5 \mathrm{ou}_{\mathrm{E}} \cdot \mathrm{m}^{-3}$. Rzeznik et al. [19] measured odour concentration in commercial deep-litter piggery. The mean value was $413 \mathrm{ou}_{\mathrm{E}} \cdot \mathrm{m}^{-3}$. Presented values are very varied. However, this is quite normal variation in sensory analyses [20]. Additionally 
for litter systems, the differences in odour concentration may be due to many factors: the type and amount of litter, bedding frequency, animal activity, temperature of air and litter, relative air humidity, etc.

The simple correlation analysis between the odour concentration and measured microclimate parameters was made. The test showed that the odour concentration statistically significantly depend on all measured microclimate parameters $(p \leq 0.05)$ (Fig. 4).
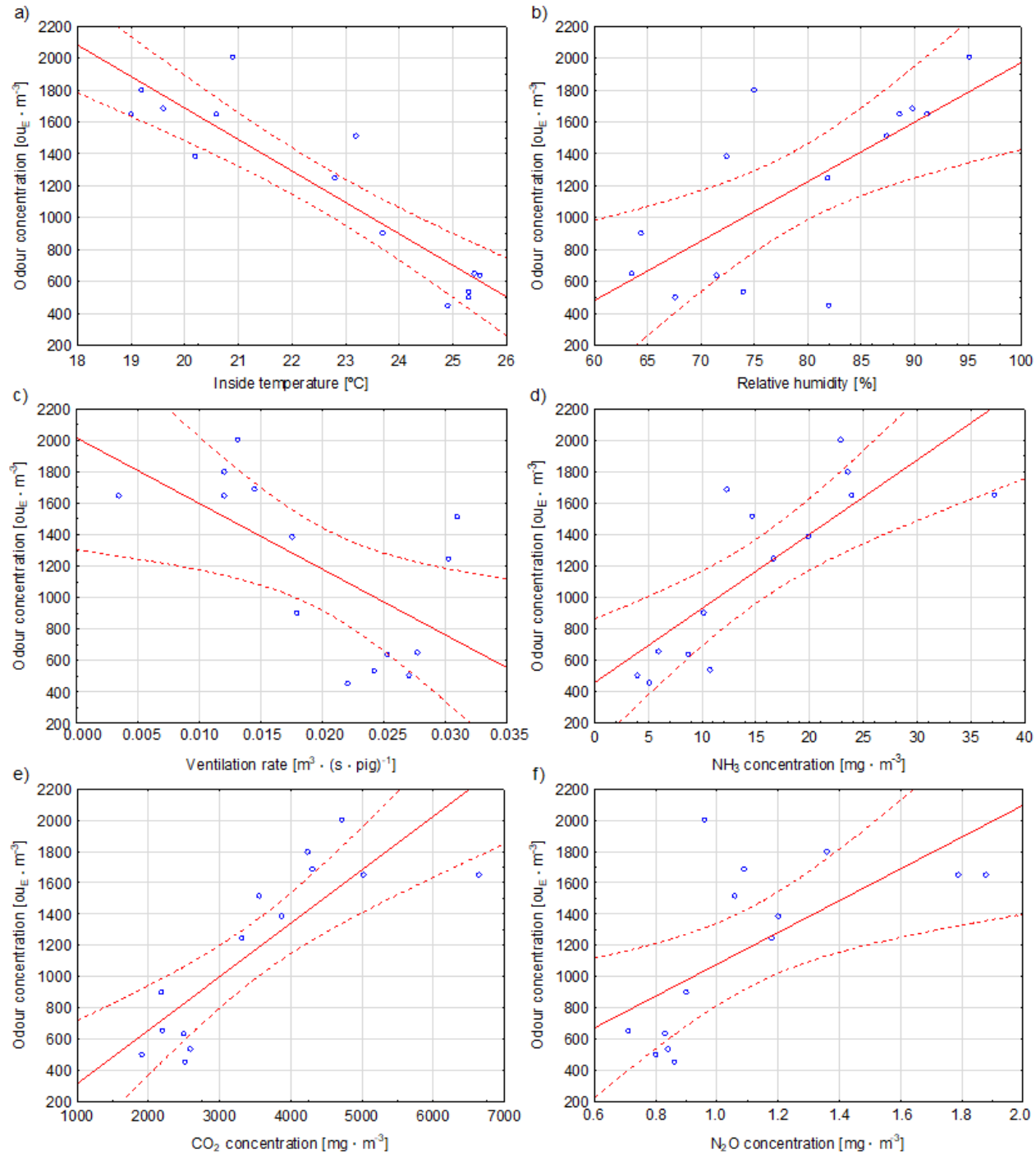

Fig. 4. Correlation diagrams between the odour concentration and measured microclimate parameters with regression line: a) $R^{2}=0.82$, b) $R^{2}=0.50$, c) $R^{2}=0.38$, d) $R^{2}=0.63$, e) $R^{2}=0.70$, f) $R^{2}=0.43$ 
It was not necessary to use many independent variables (multiple regressions) to explain the most of the variability of odour concentration. The best adjustment had the model using the inside air temperature. A statistical relationship between odour concentration and indoor temperature was described by the equation:

$$
c_{\text {od }}=5634-197 T_{\text {inside }}\left(R^{2}=0.82, p \leq 0.05\right)
$$

The impact of microclimate parameters on the odour concentration has been studied earlier, mainly in non-litter systems. However, the scope and the results of research are varied. The results similar to this study were obtained by Guo et al. [21]. They conducted annual research for pigs kept in fully-slatted systems and analysed the effect of air temperature and $\mathrm{CO}_{2}$ concentration. They showed a negative correlation of the odour concentration with the inside air temperature and the positive with the $\mathrm{CO}_{2}$ concentration. Zhou and Zhang [22] measured odour concentration and emission in ten pig houses for dry-sows, farrows and they also observed the relation between temperature and odour concentration. In other study, Guo et al. [23] analysed the diurnal variations of odour concentration in fully-slatted fattening houses. They observed no relationship between the concentration of odours and the air temperature, and ventilation rate. The effect of inside temperature and relative air humidity was studied by Choi et al. [24]. Their experiments were performed in a non-litter, solid floor pig house in January and February. The piggery was equipped with a negative pressure ventilation system and the fans operated continuously at the minimum flow rate to mainly control moisture and airborne particulates. The obtained values of correlation coefficient of odour concentration with inside temperature $R=0.62$ and with relative humidity $R=-0.43$ were lower than in this study. Furthermore the directions of the relationships were different than in this study. It may be the effect of ventilation system settings. During the measurements in climate chambers, where pigs were kept in deep-litter and fully-slatted system, Wang et al. [18] noted a strong positive correlation between the concentration of odours and air temperature, but they did not confirm the impact of ventilation rate on the odour concentration. The direction of the correlation of odour concentration and temperature could be due to constant level of ventilation rate (coefficient of variation was from 1.1 to $4.1 \%$ ). Hugle and Andree [25] studied the temperature and odour emissions from liquid manure. They noted that increasing slurry temperature from 10 to $20^{\circ} \mathrm{C}$ or $30{ }^{\circ} \mathrm{C}$ led to a four or five-fold increase in odour concentration. Sun et al. [26] conducted long-term research on odour emission from fully-slatted piggery. They noted that the simple correlations between odour concentration and microclimate parameters (inside temperature, ventilation rate, $\mathrm{CO}_{2}$ concentration) were not statistically significant and they built the mathematical model based on more variables. This model was well-fitted to empirical data $\left(R^{2}=0.67\right)$, but to get good adjustment $\left(R^{2} \geq 0.60\right)$ it was necessary to use the animal body mass as the additional variable. Yao et al. [27] studied the effect of microclimate on odour compounds concentration: $\mathrm{NH}_{3}$-ammonia, DMS-dimethyl sulphide, DMDS-dimethyl disulphide. The direction and the strength of these relationships changed during year. The whole year correlations of odour compounds with temperature were low: $R=-0.35$ for $\mathrm{NH}_{3}, R=-0.23$ for DMS and $R=-0.21$ for DMDS $(p \leq 0.05)$. The correlation coefficients between studied odour compounds and relative humidity were also low and not statistically significant. In conclusion they stated that the relationship between microclimate variables and odorous compounds is not clear. Yao et al. [28] conducted research on volatile organic compounds 
emitted from swine house. The concentrations of the odorous compounds were correlated negatively with microclimate parameters: inside temperature and ventilation rate.

\section{Odour emission factor}

The values of odour emission factor varied widely during studied period. It was from $5.76 \mathrm{ou}_{\mathrm{E}} \cdot(\mathrm{s} \cdot \mathrm{pig})^{-1}$ to $46.79 \mathrm{ou}_{\mathrm{E}} \cdot(\mathrm{s} \cdot \mathrm{pig})^{-1}$ and mean value equalled to $20.93 \mathrm{ou}_{\mathrm{E}} \cdot(\mathrm{s} \cdot \mathrm{pig})^{-1}$ (Table 3).

Table 3

Calculated odour emission factors for each day of measurement

\begin{tabular}{|c|c|}
\hline Date & $\begin{array}{c}\text { Odour emission factor } \\
\left.\left[\mathbf{o u}_{\mathbf{E}} \cdot \mathbf{( s} \cdot \mathbf{p i g}\right)^{\mathbf{- 1}}\right]\end{array}$ \\
\hline 25.03 .2014 & 5.67 \\
\hline 26.03 .2014 & 19.84 \\
\hline 27.03 .2014 & 26.18 \\
\hline 15.04 .2014 & 24.33 \\
\hline 16.04 .2014 & 21.63 \\
\hline 17.04 .2014 & 24.31 \\
\hline 24.04 .2014 & 46.79 \\
\hline 25.04 .2014 & 37.66 \\
\hline 20.05 .2014 & 16.08 \\
\hline 21.05 .2014 & 13.53 \\
\hline 22.05 .2014 & 18.00 \\
\hline 10.06 .2014 & 9.94 \\
\hline 11.06 .2014 & 16.06 \\
\hline 12.06 .2014 & 12.95 \\
\hline
\end{tabular}

This value is similar to results of measurements conducted in commercial deep-litter piggeries by Rzeznik et al. [19]. The mean odour emission factor for finishers was $16.93 \mathrm{ou}_{\mathrm{E}} \cdot(\mathrm{s} \cdot \mathrm{pig})^{-1}$. Guingand and Rugani [29] measured odour emission from deep-litter system in experimental rooms and emission factor calculated by them was $48.55 \mathrm{ou}_{\mathrm{E}} \cdot(\mathrm{s} \cdot \mathrm{pig})^{-1}$. Higher value may be due to many parameters e.g.: settings of ventilation system, animal diet, type and amount of litter, weather conditions.

Table 4

Best subset regressions (with higher adjusted $R^{2}$ ) for odour emission factor, depending on the number of the independent variables included in the model

\begin{tabular}{|c|c|c|c|c|c|c|c|}
\hline No. & $\boldsymbol{R}^{\mathbf{2}}$ & \multicolumn{7}{|c|}{ Explicative variables } & $\mathrm{NH}_{3 \text { con }}$ & $R H_{\text {inside }}$ & $\mathrm{N}_{2} \mathrm{O}_{\text {con }}$ \\
\hline 6 & 0.89 & $V R$ & $T_{\text {inside }}$ & $\mathrm{CO}_{2 \text { con }}$ & $\mathrm{NH}_{\text {con }}$ & $R H_{\text {inside }}$ & \\
\hline 5 & 0.88 & $V R$ & $T_{\text {inside }}$ & $\mathrm{CO}_{2 \text { con }}$ & $\mathrm{NH}_{3 \text { con }}$ & & \\
\hline 4 & 0.82 & $V R$ & $T_{\text {inside }}$ & $\mathrm{CO}_{2 \text { con }}$ & $\mathrm{NH}_{3 \text { con }}$ & & \\
\hline 3 & 0.82 & VR & $T_{\text {inside }}$ & $\mathrm{CO}_{2 \text { con }}$ & & & \\
\hline 2 & 0.81 & VR & $T_{\text {inside }}$ & & & & \\
\hline 1 & 0.19 & VR & & & & & \\
\hline
\end{tabular}

$T_{\text {inside }}$ is the temperature $\left[{ }^{\circ} \mathrm{C}\right] ; R H_{\text {inside }}$ is the relative humidity $[\%] ; V R$ is the ventilation rate in $\left[\mathrm{m}^{3} \cdot(\mathrm{s} \cdot \mathrm{pig})^{-1}\right]$; $\mathrm{N}_{2} \mathrm{O}_{\text {con }}, \mathrm{NH}_{3 \text { con }}$ and $\mathrm{CO}_{2 \text { con }}$ is the concentration of nitrous oxide, ammonia and carbon dioxide $\left[\mathrm{mg} \cdot \mathrm{m}^{-3}\right]$.

The simple correlation analysis did not show the relationship between odour emission factor and studied microclimate parameters. The values of correlation coefficient for all parameters were lower than 0.32 and they were not statistically significant $(p \leq 0.05)$. 
To explain the most of the variability of the odour emission it was necessary to use more independent variables (multiple regressions). Table 4 shows the combination of independent variables (for a different number of variables from 1 to 6 included in the model) with higher adjusted $R^{2}$, for odour emission factor as dependent variable. Using more independent variables resulted in better adjustment of the mathematical model to empirical data. However, the inclusion of one new variable did not improve the adjusted $R^{2}$ substantially (Table 4). This can occur, either because the effect of the variable is small, or because it is highly correlated with one variable that is already included in the model.

According to Table 4, two microclimate parameters - inside temperature and ventilation rate explained most of the variability of the odour emission factor. A statistical relationship between odour emission factor and those two statistically significant parameters $(p \leq 0.05)$ was described by the equation:

$$
E F_{\text {od }}=108+1939 \mathrm{VR}-5.5 T_{\text {inside }}\left(R^{2}=0.81, p \leq 0.05\right)
$$

There are only a few available papers describing the studies concerning the impact of microclimate parameters on the odour emission, but all of them were conducted in nonlitter piggeries. Schauberger et al. [30] found a positive correlation between the inside air temperature and the ventilation rate with odour emissions. According to their calculations, the temperature increase of $10{ }^{\circ} \mathrm{C}$ (from 20 to $30{ }^{\circ} \mathrm{C}$ ) resulted in $37 \%$ increase of odour release. Similar conclusions were presented by Le et al. [31], who studied the effect of environmental factors on odour emissions from pig manure, in laboratory scale. Guo et al. [21] showed that none of the analysed parameters affected odour emission factors. Romain et al. [32] studied the impact of ventilation rate on odour emission in fully-slatted piggery and they showed that there was no interrelation between them. Miller et al. [33] found that odour emissions decreased as temperature and relative humidity increased after monitoring 26 swine houses on 10 farms. Sun et al. [26] built the mathematical model of odour emission, where the variables were microclimate parameters (inside air temperature and ventilation rate) and animal body mass. The adjustment of model to experimental data was high $\left(R^{2}=0.85\right)$ for partially-slatted piggery, but for fully-slatted floor the coefficient of determination was much lower $\left(R^{2}=0.41\right)$.

The results obtained in this study may be helpful in preparing strategies to reduce the odours from pig fattening houses and in monitoring the odour concentrations based upon the microclimate parameters in commercial pig farms. However, this work focused only on one type of pig production group and one type of housing system. Therefore, it will be necessary and beneficial to continue the research in other types of pig houses in the future.

\section{Conclusions}

The following conclusions have been formulated upon the research:

- The mean odour concentration in studied deep-litter piggery was $1048 \mathrm{ou}_{\mathrm{E}} \cdot \mathrm{m}^{-3}$ $\left(450-2004 \mathrm{ou}_{\mathrm{E}} \cdot \mathrm{m}^{-3}\right)$ and the mean odour emission factor equaled to $20.93 \mathrm{ou}_{\mathrm{E}} \cdot(\mathrm{s} \cdot \mathrm{pig})^{-1}\left(5.76-46.79 \mathrm{ou}_{\mathrm{E}} \cdot(\mathrm{s} \cdot \mathrm{pig})^{-1}\right)$.

- The odour concentration was correlated statistically significantly $(p \leq 0.05)$ with all studied microclimate parameters: inside air temperature $(R=-0.91)$, inside relative air humidity $(R=0.71)$, ventilation rate $(R=-0.62), \mathrm{NH}_{3}(R=0.79), \mathrm{N}_{2} \mathrm{O}(R=0.66)$ and $\mathrm{CO}_{2}(R=0.84)$ concentration. 
- The statistical analysis showed that the inside temperature explained most of the variability of the odour concentration and the relationship was described by the equation: $c_{\text {od }}=5634-197 T_{\text {inside }}\left(R^{2}=0.82, p \leq 0.05\right)$.

- The most of the variability of the odour emission factor was explained by the inside temperature and ventilation rate and their relationship is given by the equation: $E F_{\text {od }}=108+1939 \mathrm{VR}-5.5 T_{\text {inside }}\left(R^{2}=0.81, p \leq 0.05\right)$.

\section{References}

[1] Scherer LA, Verburg PH, Schulp CJE. Opportunities for sustainable intensification in European agriculture. Global Environ Change. 2018;48:43-55. DOI: 10.1016/j.gloenvcha.2017.11.009.

[2] Bais-Moleman AL, Schulp CJE, Verburg PH. Assessing the environmental impacts of production- and consumption-side measures in sustainable agriculture intensification in the European Union. Geoderma. 2019;338:555-67. DOI: 10.1016/j.geoderma.2018.11.042.

[3] Rivilli S, Pettarin N, Tonino A, Snidar R, Del Frate S, Pillon A. Odour emissions from intensive pig farms. Environ Eng Manage J. 2013;12:197-200. http://www.eemj.icpm.tuiasi.ro/pdfs/vol12/no11suppl/ 51_Rivilli1_13.pdf.

[4] Cantuaria ML, Brandt J, Løfstrøm P, Blanes-Vidal V. Public perception of rural environmental quality: Moving towards a multi-pollutant approach. Atmosph Environ. 2017;170:234-44. DOI: 10.1016/j.atmosenv.2017.09.051.

[5] Wing S, Lowman A, Keil A, Marshall SW. Odors from sewage sludge and livestock: Associations with self-reported health. Public Health Reports. 2014;129:505-15. DOI: 10.1177/003335491412900609.

[6] Blanes-Vidal V, Nadimi ES, Ellermann T, Andersen HV, Løfstrøm P. Perceived annoyance from environmental odors and association with atmospheric ammonia levels in non-urban residential communities: A cross-sectional study. Environ Health Global Access Sci Source. 2012;11. DOI: 10.1186/1476-069X-11-27.

[7] Hardwick DC. Agricultural problems related to odor prevention and control. In: Nielsen VC, Voorburg JH, Hermite PL, editors. Odour Prevention and Control of Organic Sludge and Livestock Farming. New York: Elsevier Applied Science Publishers. 1985:21-26. ISBN: 9781851660100.

[8] Ubeda Y, Lopez-Jimenez P.A, Nicolas J, Calvet S. Strategies to control odours in livestock facilities: a critical review. Spanish J Agricult Res. 2013;11(4):1004-15. DOI: 10.5424/sjar/2013114-4180.

[9] Guffanti P, Pifferi V, Falciola L, Ferrante V. Analyses of odours from concentrated animal feeding operations: A review. Atmosph Environ. 2018;175:100-8. DOI: 10.1016/j.atmosenv.2017.12.007.

[10] Schauberger G, Lim TT, Ni JQ, Bundy DS, Haymore BL, Diehl CA, et al. Empirical model of odor emission from deep-pit swine finishing barns to derive a standardized odor emission factor. Atmosph Environ. 2013;66:84-90. DOI: 10.1016/j.atmosenv.2012.05.046.

[11] Hansen MJ, Nørgaard JV, Adamsen APS, Poulsen HD. Effect of reduced crude protein on ammonia, methane, and chemical odorants emitted from pig houses. Livestock Sci. 2014;169:118-24.

[12] Mielcarek P, Rzeźnik W. Odor emission factors from livestock production. Polish J Environ Stud. 2015;24:27-35. DOI: 10.15244/pjoes/29944.

[13] Szulejko JE, Kim BW, Kim KH, Lee MH, Kim YH, Jo SH, et al. Estimation of emission factor for odorants released from swine excretion slurries. Sci Total Environ. 2016;548-549:472-8. DOI: 10.1016/j.scitotenv.2016.01.031.

[14] Fukumoto M, Arima H, Ito S, Takeuchi N, Nakano H. Distorted perception of smell by volatile agents facilitated inhalational induction of anesthesia. Pediatric Anesthesia. 2005;15:98-101. DOI: 10.1111/j.1460-9592.2005.01408.x.

[15] Calvet S, Gates RS, Zhang GQ, Estelles F, Ogink NWM, Pedersen S, et al. Measuring gas emissions from livestock buildings: a review on uncertainty analysis and error sources. Biosystems Eng. 2013;116(3):221-31. DOI: 10.1016/j.biosystemseng.2012.11.004.

[16] PN-EN 13725:2007: Air Quality - Determination of odour concentration by dynamic olfactometry. Warszawa: PKN; 2007. http://sklep.pkn.pl/pn-en-13725-2007p.html.

[17] Romaniuk W, Overby T. Systemy utrzymania świń. Poradnik (The housing system of pigs. Guide). Warszawa: IBMER; 2005. ISBN 8386264985.

[18] Wang K, Wei B, Zhu S, Ye Z. Ammonia and odour emitted from deep litter and fully slatted floor systems for growing-finishing pigs. Biosystems Eng. 2011;109:203-10. DOI:10.1016/j.biosystemseng.2011.04.001.

[19] Rzeźnik W, Mielcarek P, Rzeźnik I. Limiting odour emission from piggery trough application of heat recovery system. Agricultural Eng. 2016;20:167-76. DOI: 10.1515/agriceng-2016-0017. 
[20] Van Langenhove H, De Bruyn G. Development of a procedure to determine odor emissions from animal farming for regulatory purposes in Flanders. Water Sci Technol. 2001;44(9):205-10. DOI: 10.2166/wst.2001.0541.

[21] Guo H, Wang Y, Yuan Y. Annual variations of odor concentrations and emissions from swine gestation, farrowing, and nursery buildings. J Air Waste Manage Assoc. 2011;61(12):1361-8. DOI: $10.1080 / 10473289.2011 .623636$.

[22] Zhou X, Zhang Q. Measurement of odour and hydrogen sulfide emissions from swine barns. Canad Biosystems Eng. 2003;45:6.13-6.18. http://csbe-scgab.ca/docs/journal/45/c0218.pdf.

[23] Guo H, Dehod W, Agnew J, Feddes JR, Laguë C, Pang S. Daytime odor emission variations from various swine barns. Trans ASABE. 2007;50:1365-72. DOI: 10.13031/2013.23625.

[24] Choi HL, Kim KY, Kim H. Correlation of air pollutants and thermal environment factors in a confined pig house in winter. Asian-Australasian J Animal Sci. 2005;18:574-9. DOI: 10.5713/ajas.2005.574.

[25] Hügle T, Andree H. Temperatur und Geruchsemissionen aus Flüssigmist (Temperature and Odour Emissions from Liquid Manure). Landtechnik. 2001;56:36-7. https://www.landtechnik-online.eu/landtechnik/article/ view/2001-56-1-036-037/2001-56-1-036-037-de-pdf.

[26] Sun G, Guo H, Peterson J. Seasonal odor, ammonia, hydrogen sulfide, and carbon dioxide concentrations and emissions from swine grower-finisher rooms. J Air Waste Manage Assoc. 2010;60:471-80. DOI: 10.3155/1047-3289.60.4.471.

[27] Yao HQ, Choi HL, Lee JH, Suresh A, Zhu K. Effect of microclimate on particulate matter, airborne bacteria, and odorous compounds in swine nursery houses. J Animal Sci. 2011;88:3707-14. DOI: 10.2527/jas.2009-2399.

[28] Yao HQ, Choi HL, Zhu K, Lee JH. Key volatile organic compounds emitted from swine nursery house. Atmosph Environ. 2011;45:2577-84. DOI: 10.1016/j.atmosenv.2011.01.058.

[29] Guingand N, Rugani A. Impact of the Reduction of Straw on Ammonia, GHG and Odors Emitted by Fattening Pigs Housed in a Deep-litter System. An ASABE Conference Presentation, ILES12-0083. Ninth Int Livestock Environ Symp. Valencia, Spain; 2012. DOI: 10.13031/2013.41614.

[30] Schauberger G, Lim TT, Ni JQ, Bundy DS, Haymore BL, Diehls CA, et al. Empirical model of odor emission from deep-pit swine finishing barns to derive a standardized odor emission factor. Atmosph Environ. 2013;66:84-90. DOI: 10.1016/j.atmosenv.2012.05.046.

[31] Le PD, Aarnink AJA, Ogink NWM, Verstegen MWA. Effects of environmental factors on odor emission from pig manure. Trans ASAE. 2005;48:757-65. DOI: 10.13031/2013.18318.

[32] Romain AC, Nicolas J, Cobut P, Delva J, Nicks B, Philippe FX. Continuous odour measurement from fattening pig units. Atmosph Environ. 2013;77:935-42. DOI: 10.1016/j.atmosenv.2013.06.030.

[33] Miller GY, Maghirang RG, Riskowski GL, Heber AJ, Robert MJ, Muyot MET. Influences on air quality and odor from mechanically ventilated swine finishing buildings in Illinois. Food Agricult Environ. 2004;2:353-60. https://pdfs.semanticscholar.org/699a/0d99f68c22ace784b0a7f3c9e7e7e4462efe.pdf. 